\title{
PENGARUH MOTIVASI KERJA DAN KEPEMIMPINAN TERHADAP KINERJA PEGAWAI DI DINAS KOPERASI USAHA KECIL DAN MENENGAH KABUPATEN MUSI RAWAS
}

\author{
Gregorius Wartono ${ }^{1}$, Suyadi $^{2}$ \\ Universitas Bina Insani Lubuklinggau ${ }^{1,2}$ \\ gregorius.wartono@yahoo.com ${ }^{1}$
}

\begin{abstract}
ABSTRAK
Penelitian ini bertujuan untuk mengetahui pengaruh motivasi dan lingkungan kerja terhadap Kinerja Pegawai Dinas Koperasi Usaha Kecil dan Menengah Kabupaten Musi Rawas. Sampel penelitian berjumlah 44 orang pegawai dipilih dengan dengan metode Sampling Jenuh. Hasil penelitian menunjukkan bahwa nilai $F_{\text {hitung }}(18,566)$ lebih besar dari $F_{\text {tabel }}$ 2.810. Simpulan, motivasi kerja dan kepemimpinan berpengaruh signifikan secara simultan terhadap kinerja pegawai di Dinas Koperasi Usaha Kecil dan Menengah Kabupaten Musi Rawas.
\end{abstract}

Kata Kunci : Motivasi, Kepemimpinan, Kinerja

\section{ABSTRACT}

This study aims to determine the effect of motivation and work environment on the Employee Performance of the Musi Rawas Cooperative Office for Small and Medium Enterprises. A sample of 44 employees was selected by the Saturated Sampling Method. The results showed that the calculated Fcount $(18,566)$ was greater than the Ftable 2,810. Conclusion, work motivation and leadership simultaneously have a significant effect on the performance of employees in the Department of Cooperatives of Small and Medium Enterprises in Musi Rawas Regency.

Keywords: Motivation, Leadership, Performance

\section{PENDAHULUAN}

Organisasi atau instansi pemerintah dikelola oleh orang-orang secara kolektif, agar mampu menyelesaikan permasalahan yang ada di instansi tersebut untuk mencapai tujuan organisasi. Dengan demikian aktivitas, di kalangan pegawai menuntut perhatian agar setiap pribadi dapat menggali dan mengembangkan potensi yang dimilikinya, agar dapat bekerja secara optimal.

Ada beberapa komponen penting dalam bekerja. Salah satunya kepemimpinan yang menurut Hansey (Sunyoto, 2014) setiap upaya seseorang yang mencoba untuk memengaruhi tingkah laku seseorang atau kelompok. Upaya untuk memengaruhi 
tingkah laku ini bertujuan mencapai tujuan perorangan, teman, atau bersama-sama dengan tujuan organisasi yang mungkin sama atau berbeda.

Selain kepemimpinan, dalam bekerja, motivasi merupakan hal yang perlu menjadi bahan pertimbangan utama. Motivasi berasal dari kata latin movere yang berarti dorongan atau menggerakkan. Hasibuan (2014) menyatakan bahwa motivasi merupakan suatu keahlian, dalam menggerakkan personil dan organisasi agar mau bekerja secara berhasil, sehingga keinginan para personil dan tujuan organisasi sekaligus tercapai. Kepemimpinan dan motivasi kerja yang ada di suatu organisasi dimaksudkan untuk mencapai seoptimal mungkin kinerja.Pencapaian itu meliputi kinerja individual, unit, maupun organisasi dalam rangka pencapaian visi dan misi instansi pemerintah.

Dinas Koperasi Usaha Kecil dan Menengah Kabupaten Musi Rawas dibentuk sesuai dengan Peraturan Bupati Musi Rawas Nomor 56 Tahun 2016. Merupakan unsur pelaksana urusan Pemerintah yang menangani urusan pemerintah daerah di bidang koperasi, usaha kecil dan menengah. Dinas Koperasi Usaha Kecil dan Menengah Kabupaten Musi Rawas dipimpin oleh Kepala Dinas yang berkedudukan di bawah dan bertanggung jawab kepada Bupati melalui Sekretaris Daerah.

Dengan fungsi penyusunan perencanaan bidang koperasi, usaha kecil dan menengah. Perumusan kebijakan teknis bidang koperasi, usaha kecil dan mrnengah. Pelaksanaan urusan pemerintahdan pelayanan umum bidang koperasi, usaha kecil dan menengah. Pembinaan, koordinasi, pengendalian dan fasilitasi pelaksanaan kegiatan bidang koperasi, usaha kecil dan menengah.

Pengamatan awal yang dilakukan peneliti dapat diketahui bahwa, pegawai belum optimal hasil kinerjanya. Kepemimpinan yang ada terlihat masih kurang, khususnya dalam memberikan motivasi kepada pegawai. Pimpinan dalam memberikan pengarahan ataupun penjelasan belum dapat memotivasi pegawai untuk lebih optimal dan efisien. Pimpinan dalam mengambil putusan, masih belum memerhatikan masukan ataupun saran dari bawahan. Pimpinan masih kurang memahami fakta yang ada di lapangan. Pimpinan belum memberikan rasa aman bagi pegawai dalam melaksanakan pekerjaan yang menjadi tanggung jawab mereka. 


\section{KAJIAN TEORI \\ Pengertian Kinerja Karyawan}

Pengertian kinerja karyawan menurut Hasibuan (2014) adalah "suatu hasil kerja yang dicapai seseorang dalam melaksanakn tugas-tugas yang dibebankan kepadanya didasarkan atas kecakapan, pengalaman, dan kesungguhan serta waktu”. Menurut Mangkunegara (2006) kinerja adalah hasil kerja secara kualitas dan kuantitas yang dicapai oleh seorang pegawai dalam melaksanakan tugasnya sesuai dengan tanggung jawab yang diberikan kepadanya. Faktor yang mempengaruhi pencapaian kinerja adalah kemampuan (ability) dan faktor motivasi (motivation) menurut Mathis (2002) Kinerja karyawan adalah apa yang dilakukan oleh seorang karyawan yang mempengaruhi seberapa banyak mereka memberi kontribusi kepada organisasi yaitu dalam arti kualitas, kuantitas output, jangka waktu output, kehadiran di tempat kerja, dan sikap kooperatif. Dari pendapat di atas dapat ditarik kesimpulan bahwa kinerja karyawan adalah merupakan suatu tingkat kemajuan seorang karyawan atas hasil dari usahanya untuk meningkatkan kemampuan secara positif dalam pekerjaannya.

Faktor-faktor yang mempengaruhi Kinerja karyawan menurut Davis yang dikutip oleh Mangkunegara (2006):

Faktor kemampuan secara psikologis, kemampuan (ability) pegawai terdiri dari kemapuan potensi (IQ) dan kemampuan realiti (knowladge+skill) artinya pegawai yang memiliki IQ di atas rata - rata ( IQ 110-120) dengan pendidikan yang memadai untuk jabatanya dan terampil dalam mengerjakan pekerjaan sehari-hari, maka ia akan lebih mudah mencapai kinerja yang diharapkan. Oleh karena itu pegawai perlu ditetapkan pada pekerjaan yang sesuai dengan keahlian (the right man on the right place, the right man on the the right job).

Faktor Motivasi terbentuk dari sikap (attitude) seseornag pegawai dalam menghadapi situasi (situation) kerja, sikap mental seorang pegawai harus sikap mental yang siap secara psikologis artinya seorang pegawai harus siap mental, mampu secara fisik, memahami tujuan utama dan target kerja yang akan dicapai mampu memanfaatkan dan menciptakan situasi kerja. Menurut pendapat clelland yang dikutip oleh Mangkunegara (2007) bahwa Ada hubungan yang positif antara motif yang berprestasi dengan pencapain kinerja. 
Motif berprestasi adalah dorongan dalam diri pegawai untuk melakukan suatu kegiatan atau tugas dengan sebaik-baiknya agar mampu mencapai prestasi kerja (kinerja) yang predikat terpuji. Berdasarkan pendapat Clelland tersebut, karyawan akan mampu mencapai kinerja maksimal jika ia memiliki motif berprestasi tinggi. Motif berprestasi yang perlu dimiliki karyawan harus ditumbuhkan dari dalam diri sendiri selain dari lingkungan kerja. Hal ini karena motif berprestasi yang ditumbuhkan dalam diri sendiri akan membentuk suatu kekuatan diri dan jika situasi lingkungan kerja ikut menunjang maka mencapai tujuan yang akan lebih mudah.

\section{Pengertian Kepemimpinan}

Kepemimpinan terkadang dipahami sebagai kekuatan untuk menggerakan dan mempengaruhi orang. Kepemimpinan sebagai sebuah alat, sarana atau peroses untuk membujuk orang agar bersedia melakukan sesuatu secara sukarela atau sukacita. Ada beberapa faktor yang dapat menggeraakkan orang karena ancaman, penghargaan, otoritas, dan bujukan. Kemudian Rivai, Veitzhal (2014) menjelaskan bahwa kepemimpinan merupakan proses mempengaruhi dalam menentukan tujuan organisasi, memotivasi perilaku pengikut untuk mencapai tujuan, mempengaruhi untuk memperbaiki kelompok dan budayanya. Selain itu juga mempengaruhi interprestasi mengenai pristiwa-pristiwa para pengikutnya, pengorganisasian dan aktivitas-aktivitas untuk mencapai sasaran, memelihara hubungan kerja sama dan kerja kelompok, perolehan dukungan dan kerja sama dari orang-orang di luar kelompok atau organisasi.

Menurut Hasibuan (2007) Kepemimpinan adalah cara seorang pemimpin mempengaruhi perilaku bawahan, agar mau bekerjasama dan bekerja secara produktif untuk mencapai tujuan organisasi”. Berdasarkan definisi-definisi kepemimpinan diatas dapat ditarik kesimpulan bahwa kepemimpinan adalah bagian yang dianggap penting dalam manajemen organisasi, yang dimana melekat pada diri seorang pemimpin dalam bentuk kemampuan dan atau proses untuk mempengaruhi orang lain atau bawahan perorangan atau kelompok, agar bawahan perorangan atau kelompok itu mau berperilaku seperti apa yang dikehendaki pemimpin, dan memperbaiki budayanya, serta memotivasi perilaku bawahan dan mengarahkan ke dalam aktivitas-aktivitas positif yang ada hubungannya dengan pekerjaan dalam rangka mencapai tujuan organisasi. 


\section{Teori-teori Kepemimpinan}

Dalam Mulyadi, Rivai (2009) dikemukakan beberapa teori kepemimpinan, yaitu:

Teori Sifat, Teori ini memandang kepemimpinan sebagai suatu kombinasi sifatsifat yang tampak dari pemimpin. Asumsi dasar dari teori ini adalah keberhasilan pemimpin disebabkan karena sifat atau karakteristik, dan kemampuan yang luar biasa yang dimiliki seorang pemimpin, dan oleh sebab itu seseorang dirasa layak untuk memimpin. Adapun sifat atau karakteristik, dan kemampuan yang luar biasa yang dimiliki seorang pemimpin, antara lain:

Inteligensia. Seorang pemimpin memiliki kecerdasan diatas para bawahannya. Pemimpin dengan kecerdasannya itulah dapat mengatasi masalah yang timbul dalam organisasi, dengan cepat mengetahui permasalahan apa yang timbul dalam organisasi, menganalisis setiap permasalahan, dan dapat memberikan solusi yang efektif, serta dapat diterima semua pihak.

Kepribadian. Seorang pemimpin memiliki kepribadian yang menonjol yang dapat dilihat dan dirasakan bawahannya, seperti: Memiliki sifat percaya diri, dan rasa ingin tau yang besar. Memiliki daya ingat yang kuat. Sederhana, dan dapat berkomunikasi dengan baik kepada semua pihak. Mau mendengarkan masukan (ide), dan kritikan dari bawahan. Peka terhadap perubahan globalisasi, baik itu perubahan lingkungan, teknologi, dan prosedur kerja. Mampu beadaptasi dengan perubahanperubahan yang timbul. Berani dan tegas dalam melaksanakan tugas pokoknya, dan dalam mengambil sikap, serta mengambil keputusan bagi kepentingan organisasi dan pegawainya. Mampu menyatukan perbedaan-perbedaan yang ada dalam organisasi.

Karakteristik fisik. Seorang pemimpin dikatakan layak menjadi pemimpin dengan melihat karakteristik fisiknya, yaitu: usia, tinggi badan, berat badan, dan penampilan. Teori perilaku. Dalam teori ini perilaku pemimpin merupakan sesuatu yang bisa dipelajari. Jadi seseorang yang dilatih dengan kepemimpinan yang tepat akan meraih keefektifan dalam memimpin. Teori ini memusatkan perhatiannya pada dua aspek perilaku kepemimpinan, yaitu: fungsi kepemimpinan, dan gaya kepemimpinan. Terdapat dua fungsi kepemimpinan, yaitu:

Fungsi yang berorientasi tugas. Fungsi yang berorientasi orang atau pemeliharan kelompok (sosial). Teori situasional, Merupakan suatu pendekatan terhadap kepemimpinan yang menyatakan bahwa pemimpin memahami perilakunya, sifat-sifat 
bawahannya, dan situasi sebelum menggunakan suatu gaya kepemimpinan tertentu. Pendekatan ataupun teori ini mensyaratkan pemimpin untuk memiliki keterampilan diagnostik dalam perilaku manusia.

\section{Ciri-Ciri Kepemimpinan}

Menurut Davis yang dikutip oleh Reksohadiprodjo, Handoko (2003) ciri-ciri utama yang harus dimiliki oleh seorang pemimpin :

Kecerdasan (intelligence) Penelitian-penelitian pada umumnya menunjukkan bahwa seorang pemimpin yang mempunyai tingkat kecerdasan yang lebih tinggi daripada pengikutnya, tetapi tidak sangat berbeda.

Kedewasaan, Sosial dan Hubungan Sosial yang luas (Social maturity and Breadht) Pemimpin cenderung mempunyai emosi yang stabil dan dewasa atau matang, serta mempunyai kegiatan dan perhatian yang luas.

Motivasi diri dan dorongan berprestasi Pemimpin secara relatif mempunyai motivasi dan dorongan berprestasi yang tinggi, mereka berkerja keras lebih untuk nilai instrinsik. Sikap-sikap hubungan manusiawi Seorang pemimpin yang sukses akan mengakui harga diri dan martabat pengikut-pengikutnya, mempunyai perhatian yang tinggi dan berorientasi pada bawahannya. Berdasarkan uraian di atas, dapat disimpulkan bahwa seorang pemimpin harus mempunyai tingkat kecerdasan yang lebih tinggi dari pada bawahanya dan mempunyai motivasi dan dorongan berprestasi yang tinggi pula.

\section{Sifat-sifat Kepemimpinan}

Secara umum sifat - sifat yang perlu dimiliki oleh seorang pemimpin adalah Pandojo (2003) Keinginan untuk menerima tanggung jawab Apabila seorang pemimpin menerima kewajiban untuk mencapai suatu tujuan, berarti ia bersedia untuk bertanggung jawab kepada pimpinannya terhadap apa yang dilakukan bawahannya, mengatasi tekanan kelompok informal, bahkan kalau perlu dari organisasi buruh.

Kemampuan untuk bisa perceptive Perceptive (persepsi) menunjukkan kemampuan untuk mengamati atau menemukan kenyataan dari suatu lingkungan. Ia memerlukan kemampuan untuk memahami bawahannya, sehingga ia dapat mengetahui kekuatan dan kelemahan mereka serta berbagi ambisi yang ada. Disamping itu ia juga harus mempunyai persepsi introspektif (memandang atau menilai dirinya sendiri) sehingga ia bisa mengetahui kekuatan, kelemahan dan tujuan yang layak baginya 


\section{METODE PENELITIAN}

\section{Jenis Penelitian dan Sumber Data}

Jenis penelitian ini adalah asosiatif menggunakan metode survey yang bersumber dari data Pegawai Dinas Koperasi Usaha Kecil dan Menengah Kabupaten Musi Rawas Musi Rawas. Dalam peneliian ini menggunakan dua jenis data yaitu data primer dan data sekunder.

\section{Populasi dan Sampel}

Populasi dalam penelitian ini seluruh Pegawai Dinas Koperasi Usaha Kecil dan Menengah Kabupaten Musi Rawas Musi Rawas. yang berjumlah 44 Pegawai. Dengan sampel penelitian menggunakan sampel total seluruh populasi pegawai pada kantor tersebut.

\section{Metode Analisis}

\section{Uji Asumsi Klasik}

Uji asumsi klasik dilakukan secara bersamaan dengan proses uji regresi. Model regresi linear berganda dapat disebut sebagai model yang baik jika model tersebut memenuhi asumsi klasik statistik yang meliputi uji normalitas, multikolineritas, dan heteroskedastisitas.

\section{Uji Analisis Regresi Linier Berganda}

Analisis Regreasi Linier Berganda : $\mathrm{Y}=\mathrm{a}+\mathrm{b} 1$

$$
\mathrm{X} 1+\mathrm{b} 2 \mathrm{X}_{2}
$$

Dimana:

$\mathrm{Y}=$ Kinerja Pegawai X1 = Motivasi Kerja X2 = Kepemimpinan

\section{HASIL PENELITIAN}

Untuk Mengukur besarnya persentase sumbangan variabel bebas dan variabel terikat secara keseluruhan, maka diukur besarnya koefisien korelasi. Nilai koefisien korelasi (R) variabel bebas Pengaruh Motivasi Kerja (X1) yang diperoleh, adalah sebesar 0,651. Hal ini dapat diartikan bahwa hubungan antara variabel bebas Pengaruh Motivasi (X1) terhadap variabel terikat Kinerja Pegawai (Y) secara parsial dapat dikatakan cukup. Korelasi di antara motivasi dan kinerja pegawai adalah $42.4 \%$. 
Sisanya (100-42.4) 57.6\% dipengaruhi oleh variabel lain yang tidak termasuk dalam penelitian. Untuk melihat pengaruh parsial dari masing-masing variabel bebas terhadap variabel terikat dapat dijelaskan dengan menggunakan uji t. Berdasarkan hasil perhitungan uji t bahwa Variabel Pengaruh Motivasi (X1) terhadap Kinerja Pegawai (Y) menunjukan nilai thitung $=5.555$ lebih besar dari nilai tabel (2.014) dengan tingkat signifikansi $\operatorname{sig}=0.05$. Hal ini berarti dapat disimpulkan bahwa secara parsial Motivasi berpengaruh signifikan terhadap Kinerja Pegawai pada Dinas Koperasi Usaha Kecil dan Menengah Kabupaten Musi Rawas.

Uji regresi linear sederhana digunakan mengetahui pengaruh Kepemimpinan terhadap Kinerja pegawai pada Dinas Koperasi Usaha Kecil dan Menengah Kabupaten Musi Rawas. Dari hasil rekapitulasi hasil regresi linear sederhana adalah sebagai berikut : $\mathrm{Y}=53.869+0.496 \mathrm{X} 2$. Dari persamaan nilai estimasi fungsi regresi di atas terlihat bahwa nilai konstanta yang diperoleh adalah sebesar a $=53.869$. Hal inimenggambarkan bahwa tanpa dipengaruhi oleh variabel bebas Kepemimpinan (X2), maka Kinerja Pegawai (Y) adalah sebesar 53.869. Nilai koefisien regresi mewakili variabel Kepemimpinan yang diperoleh sebesar b2 $=0.496$ menunjukkan bahwa setiap perubahan pada satu kesatuan Kepemimpinan, maka Kinerja Pegawai akan berubah berbanding lurus, yakni sebesar 0.496 .

Untuk mengukur besarnya persentase sumbangan variabel bebas dan variabel terikat secara keseluruhan. Nilai koefisien korelasi (R) variabel bebas yang diperoleh adalah sebesar 0.261. HaI ini dapat diartikan bahwa hubungan antara variabel bebas Kepemimpinan (X2) terhadap variabel terikat. Kinerja Pegawai (Y) secara parsial dapat dikatakan cukup memiliki korelasi sebesar $6.8 \%$ dan ia disebut hubungan yang tidak kuat. Sisanya, 93.2\% dipengaruhi oleh variabel lain yang tidak termasuk dalam variabel penelitian.

Untuk melihat pengaruh parsial dari masing-masing variabel bebas terhadap variabel terikat dapat dijelaskan dengan menggunakan uji t. Berdasarkan hasil perhitungan uji t bahwa Variabel Kepemimpinan (X2) terhadap Kinerja Pegawai (Y) menunjukkaan nilai thitung $=1.752$ lebih kecil dari nilai tabel $=2.014$ dengan tingkat signifikansi sig. $=0,05$. Hal ini berati dapat disimpulkan bahwa secara parsial Kepemimpinan berpengaruh tidak signifikan terhadap Kinerja pegawai pada Dinas Koperasi Usaha Kecil dan Menengah Kabupaten Musi Rawas dapat dikatakan kurang. 


\section{PEMBAHASAN}

\section{Pengaruh Kepemimpinan terhadap Kinerja Pegawai}

Uji regresi linear berganda digunakan trntuk mengetahui pengaruh data primer yang diuji, yang berasal dari 2 variabel bebas yaitu pengaruh Motivasi dan Kepemimpinan terhadap Kinerja Pegawai. Dari hasil rekapitulasi hasi regresi linear berganda di atas adapun persamaan regresi untuk mengestimasi variabel terikat dengan menggunakan seluruh variabel bebas adalah sebagai berikut: $\mathrm{Y}=16.502+0.683 \mathrm{X} 1$ + 0432 X2 Hasil uji Regresi Linear berganda menunjukan bahwa Nilai (constant) (a) sebesar 16.502 artinya jika nilai variabel independen (Motivasi dan Kepemimpinan) nol maka nilai varibel dependen (Kinerja) sebesar 16.502 dalam hal ini bila variabel independen naik atau bepengaruh dalam satu satuan, maka variabel bebas akan naik atau terpenuhi.

Nilai koefisien regresi variabel motivasi (X1) terhadap variabel kerja (Y) sebesar $b_{1}=0,683$ artinya jika motivasi $\left(X_{1}\right)$ mengalami kenaikan satu satuan, maka akan mengalami peningkatan kinerja sebesar 0,683. Nilai koefisien regresi variabel kepemimpinan $\left(\mathrm{X}_{2}\right)$ terhadap kinerja $(\mathrm{Y})$ sebesar b2=0.432 artinya jika kepemimpinan (X2) mengalami kenaikan satu satuan, maka akan mengalami peningkatan Kinerja sebesar b2 $=0.432$. Nilai koefisien determinan $\left(R^{2}\right)$ yang diperoleh, adalah sebesar 0,689, dapat diartikan bahwa variasi perubahan nilai variabel terikat (Kinerja) dapat dijelaskan oleh seluruh variabel bebas (Motivasi dan Kepemimpinan) secara bersamasama (simultan) sebesar 47,5\% dan sisanya sebesar 52,5\% dipengaruhi oleh variabelvariabel lain.

Uji serentak/simultan (uji F) dilakukan untuk melihat pengaruh dari variabel bebas terhadap variabel terikat secara bersama. Berdasarkan rekapitulasi hasil uji regresi linier berganda, didapat bahwa nilai Fhitung yang diperoleh adalah 18.566 Ftabel $=2.810$ dan tingkat kemaknaan secara serentak sig $\mathrm{F}$ adalah 18.566. Hal ini menurjukkan bahwa secara bersama-sama (simultan) variabel bebas penelitian (motivasi dan kepemimpinan) memiliki pengaruh yang signifikan terhadap variabel terikat (kinerja).

Hasil uji serentak/simultan (uji F) ini juga membuktikan bahwa hipotesis ketiga penelitian ini yang berbunyi Motivasi Kerja dan Kepemimpinan berpengaruh signifikan 
terhadap kinerja pegawai pada dinas koperasi usaha kecil dan menengah Kabupaten Musi Rawas.

Sebuah organisasi pemerintah daerah memiliki sumber daya manusia yang penting peranannya dalam menjaga kelangsungan hidup organisasi pemerintah daerah. Berhasil atau tidaknya organisasi pemerintah daerah dalam mencapai tujuan, sumber daya manusia menjadi salah satu faktor penentunya. Keberhasilan dalam pencapaian tujuan organisasi pemerintah daerah didasari oleh sumber daya manusia yang berkualitas dan tergantung bagaimana organisasi pemerintah daerah mampu memanfaatkan peluang yang ada dan mengatasi ancaman dari luar dengan memanfaatkan sumber daya manusia yang dimiliki (Rumondor et al., 2016).

Ada beberapa komponen penting dalam bekerja. Salah satunya kepemimpinan yang menurut Hansey (Sunyoto, 2015) setiap upaya seseorang yang mencoba untuk memengaruhi tingkah laku seseorang atau kelompok. Upaya untuk memengaruhi tingkah laku ini bertujuan mencapai tujuan perorangan, teman, atau bersama-sama dengan tujuan organisasi yang mungkin sama atau berbeda.

Selain kepemimpinan, dalam bekerja, motivasi merupakan hal yang perlu menjadi bahan pertimbangan utama. Motivasi berasal dari kata latin movere yang berarti dorongan atau menggerakkan. Hasibuan (2014) menyatakan bahwa motivasi merupakan suatu keahlian, dalam menggerakkan personil dan organisasi agar mau bekerja secara berhasil, sehingga keinginan para personil dan tujuan organisasi sekaligus tercapai. Kepemimpinan dan motivasi kerja yang ada di suatu organisasi dimaksudkan untuk mencapai seoptimal mungkin kinerja.Pencapaian itu meliputi kinerja individual, unit, maupun organisasi dalam rangka pencapaian visi dan misi instansi pemerintah.

Dinas Koperasi Usaha Kecil dan Menengah Kabupaten Musi Rawas dibentuk sesuai dengan Peraturan Bupati Musi Rawas Nomor 56 Tahun 2016. Merupakan unsur pelaksana urusan Pemerintah yang menangani urusan pemerintah daerah di bidang koperasi, usaha kecil dan menengah. Dinas Koperasi Usaha Kecil dan Menengah Kabupaten Musi Rawas dipimpin oleh Kepala Dinas yang berkedudukan di bawah dan bertanggung jawab kepada Bupati melalui Sekretaris Daerah.

Dengan fungsi penyusunan perencanaan bidang koperasi, usaha kecil dan menengah. Perumusan kebijakan teknis bidang koperasi, usaha kecil dan mrnengah. Pelaksanaan urusan pemerintahdan pelayanan umum bidang koperasi, usaha kecil dan 
menengah. Pembinaan, koordinasi, pengendalian dan fasilitasi pelaksanaan kegiatan bidang koperasi, usaha kecil dan menengah.

\section{SIMPULAN}

1. Motivasi kerja berpengaruh signifikan secara parsial terhadap kinerja pegawai di Dinas Koperasi Usaha Kecil dan Menengah Kabupaten Musi Rawas.

2. Kepemimpinan berpengaruh tidak signifikan secara parsial terhadap kinerja pegawai di Dinas Koperasi Usaha Kecil dan Menengah Kabupaten Musi Rawas.

3. Motivasi kerja dan kepemimpinan berpengaruh signifikan secara simultan terhadap kinerja pegawai di Dinas Koperasi Usaha Kecil dan Menengah Kabupaten Musi Rawas.

\section{DAFTAR PUSTAKA}

Handoko, T., Hani, H., \& Reksohadiprodjo, R. (2003). Manajemen Sumber Daya Manusia dan Perusahaan. Edisi Kedua. Yogyakarta: BPFE

Hasibuan, M. (2014). Sumber Daya Manusia Edisi Revisi. Jakarta: Bumi Aksara

Mangkunegara, A. P. (2007). Manajemen Sumber Daya Manusia Perusahaan. Bandung: PT. Remaja Rosdakarya

Mangkunegara, M. (2006). Evaluasi Kinerja Sumber Daya Manusia. Bandung : Rafika Aditama

Mathis, R. L., \& John H. J. (2002). Human Resource Management. Buku 2. Edisi Pertama. Jakarta: Salemba Empat

Mulyadi, M., \& Rivai, R. (2009). Manajemen Sumber Daya Manusia. Jakarta

Ranupandojo, H., \& Husnan, S. (2003). Manajemen Personalia. Edisi Kedua. Yogyakarta: BPFE UGM

Rivai, R., \& Veithzal, V. (2014). Manajemen Sumber Daya Manusia untuk Perusahaan: dari Teori Ke Praktik, Edisi Pertama. Jakarta: Penerbit PT. Raja Grafindo Persada

Rumondor, R. B., Tumbel, A., \& Jantje, L. S. (2016). Pengaruh Kepemimpinan, Motivasi, dan Disiplin Kerja terhadap Kinerja Pegawai pada Kanwil Ditjen Kekayaan Negara Suluttenggomalut. Jurnal EMBA, 4(2), 254-256

Sunyoto, D. (2014). Manajemen Sumber Daya Manusia. Jakarta: PT Buku Seru. http://repository.upi.edu/17628/4/S_MB S_1001311_Bibliography 